\title{
NUEVAS PINTURAS DE LUCA CAMBIASO EN ESPAÑA
}

El duro juicio de fray José de Sigüenza sobre las pinturas de San Miguel arcángel y de Santa Úrsula y las oncemil Virgenes realizadas por Cambiaso para El Escorial - «parece que las hizo no mas de para ganar de comer aquel día», sentencia sin reparo ${ }^{1}$ - bien podría hacerse extensivo al grueso de las que para los altares del monasterio realizara el genovés, cuya casi general desmaña se hace notar al compararlas con las de autores bastante más modestos como Diego de Urbina, Carvajal o Barroso, por no nombrar a Navarrete o Sánchez Coello. Lo poco cuidado de la ejecución y la carencia de detalles determinaron que el jerónimo las calificara de obras "andaderas» y "poco más que bosquejadas»; y tampoco puede decirse, desde luego, que destacaran por su acierto compositivo, en lo que sobresale la Predicación del Bautista. El mismo fray José declara que tampoco fueron del agrado del rey «así por la compostura de las historias como por el poco ornato que tienen las figuras, y un colorido muerto, sin gracia» ${ }^{2}$, y no es otro el juicio que bastantes años después formulara alguien bastante más versado en el tema como era Palomino ${ }^{3}$.

Pero no hay duda de que el genovés es uno de los pintores más creativos de la segunda mitad del siglo Xvi y artista de singular tesitura estilística. Más allá de las brillantes decoraciones del palacio Grillo, el palacio Lercari, el della Meridiana o el Pessagno, o de las villas Pallaviccini e Imperiale, desarrolladas en sus años tempranos con pleno criterio manierista, o de las abstractas reducciones robóticas de sus dibujos, Cambiaso es pintor de nocturnos líricos, de figuras melancólicas y de una poética de las formas silentes -Georges Latour avant la lettre-, que acomoda a los temas religiosos en el renovado clima de la Contrarreforma, y, en su faceta más pietista, autor de devotos pasajes pictóricos de la Pasión y de epifanías íntimas, de gran intesidad y sensibilidad. No es de extrañar que con tales credenciales y su notable prestigio se pensara en él para cubrir el vacío dejado por el fallecimiento de El Mudo, aunque fueron sus dotes de decorador y de creador de altares las que determinaron esta circunstancia, sumadas en buena medida su proverbial prestezza ${ }^{4}$.

Que su fama le precedía se pone ya de manifiesto en varias composiciones de Alonso Sánchez Coello en el retablo mayor de El Espinar (1574-1577), directamente deudoras de pinturas o dibujos suyos ${ }^{5}$, y que tuvo continuidad e influencia a más largo plazo se hace patente también aquí en la obra de Sánchez Cotán.

1 Fray José de Sigüenza, Historia de la Orden de San Jerónimo, 1600-1605; Fundación del Monasterio de El Escorial, en ed. Madrid, Aguilar, 1963, Libro IV, discurso VII, pág. 265. Pellegrino Tibaldi hizo en 1592 sendas pinturas del mismo tema para los mismos altares, de los que se retiraron las de Cambiaso.

2 Sigüenza, op. cit., pág. 265.

3 Ascisclo Antonio Palomino, Museo pictórico y Escala Óptica. Madrid, Aguilar, 1947, pág. 798: "verdaderamente hay cosas que aunque en lo escrito y discurrido son muy buenas; en el arte no tienen capricho, ni armonía pintoresca». Frente a la medianía de sus pinturas escurialenses, el cordobés no pudo menos que reconocer que mientras en su pintura no tuvo buen gusto, en los dibujos fue excelente, de gran magisterio y creatividad.

4 El renombrado Descendimiento de Santa Clara de San Martin d'Albaro fue realizado en el breve plazo de tres días. La conveniencia de tal celeridad para acometer la pintura de las bóvedas escurialenses, mencionada por el P. Sigüenza, reportaría una pérdida de calidad tal que el mismo Pompeyo Leoni no lo pudo pasar por alto para justificar su tardanza en la terminación del retablo mayor (Rosemarie Mulcahy, "A mayor gloria de Dios y del Rey»: La decoración de la Real Basilica del monasterio de El Escorial. Madrid, 1992, pág. 85).

5 En especial la tabla de la Natividad y el Entierro de Cristo, en la cortina, donde Sánchez Coello se limita a seguir lo realizado por el genovés, sobre los modelos de la colección Manning (N. Y.) y del gabinete de dibujos de los Uffizi, respectivamente (F. Collar de Cáceres, Pintura en la antigua diócesis de Segovia. Segovia, 1989, vol. 1, pág. 223; cf. además el catálogo de la exposición Alonso Sánchez Coello y el retrato en la Corte de Felipe II, Madrid, Museo del Prado, junio-julio 1990, M. del Prado, págs. 117-118), pero también en la pintura de la Resurrección, que no puede ocultar su dependencia de la de San Martín de Montalto, y en menor grado, pero también de manera indudable, en la Pentecostés y la Purificación, aunque con mayor reelaboración, a partir de las versiones del Palazzo Bianco y de las desaparecidas pinturas del palacio episcopal de Génova. Están por determinar las vías y razones de tan temprano y amplio conocimiento de la obra de Cambiaso por parte del maestro valenciano. 
La llegada a España en 1581 de un lienzo del Martirio de San Lorenzo para el retablo mayor del monasterio, pagado a Nicolás Granello - hijastro del Bergamasco- que lo trajo desde Génova, fue sin embargo la verdadera y poco afortunada carta de presentación del ya maduro Luqueto. Es claro que la obra no gustó y se juzgó inadecuada para el retablo mayor, sin que ello fuera suficiente para prevenir sobre su mermada capacidad creadora en grandes composiciones. El reducido tamaño de las figuras pudo en efecto determinar que el lienzo resultara poco apropiado para el lugar al que estaba destinado, muy lejos de la vivacidad y la belleza de la versión de San Lorenzo della Costa, y quedó definitivamente relegado ${ }^{6}$; a la larga su espacio sería ocupado por la pintura del mismo asunto que acabó por encomendarse a Tibaldi 7 .

Las gestiones para la venida de Cambiaso a España fueron realizadas como es bien sabido por el embajador Pedro de Mendoza desde comienzos de $1583^{8}$, y chocaron en principio con las reticencias del maestro. Sigüenza especifica que «fue traydo por famoso y por valiente», lo que se hizo "...para las cosas del fresco, en que tenía mucha práctica", si bien no oculta contradictorias cualidades del pintor, indicando que Luqueto, «hombre facilísimo en el arte, de estraña presteza y no falta de invención, aunque sí notablemente de adorno" ${ }^{9}$. La más acertada resolución de la pintura de la Predicación de San Juan Bautista, en otro de los altares del monasterio, es tomada por el historiador jerónimo para recalcar la pobreza y descuido de las otras creaciones escurialenses del artista de Mondeglia ${ }^{10}$, al ser lo único que respondía a las expectativas despertadas por composiciones como las de las capillas Spinola y Zoagli en la Annunziata de Portoria o de la capilla Lercari en la catedral de San Lorenzo de Génova.

Sus dos años de actividad en España, desde su llegada por noviembre de 1583, los ocupó principalmente en la creación de los altares y de una bóveda que le supuso quince meses de actividad, esfuerzo sobrehumano que a juicio de fray José de Sigüenza le costo la vida ${ }^{11}$. El sentido didáctico de la empresa, acorde con la conciencia postrentina sobre el valor de las imágenes religiosas (formar, informar, conmover), mereció la aprobación de Sigüenza y probablemente del monarca, aunque no podían faltar algunas objeciones derivadas de la celérica ejecución del fresco: ...«y si el colorido y ornato de los paños no fueran en las pinturas de Luqueto de tan corrida y azelerada manera, sin duda fuera esta gloria una de las más ilustres obras que teníamos en esta fábrica» ${ }^{12}$; hoy es conjunto que repele por su monotonía, su falta de vida y su carencia de atmósfera.

6 De muy otra forma lo fueron las alargadas pinturas de Tintoretto y del Veronés, traídas así mismo por Granello, haciendo las veces de agente artístico, y el extraordinario Martirio de San Lorenzo realizado por Tiziano, o el que tras el de Cambiaso hizo Zuccaro, también rechazado.

7 R. Mulcahy The High Altarpiece of the Basilica of San Lorenzo de El Escorial: an Unpublished Document» Burlington. Magazine' 1980, págs. 188-192. Antes de todo ello la pintura fue encomendada a Navarrete, y tras la llegada de la obra de Cambiaso se encargó otra a Zuccaro. Sobre las pinturas del retablo y su historia Annie Cloulas-Brousseau "Les peintures du grand retable au monastère de l'Escurial», Mélanges de la Casa de Velázquez, vol. IV (1968), págs. 173-202.

8 Rosa López Torrijos, "Documentos genoveses para la venida de Luca Cambiaso a España", en Real Monasterio-Palacio de El Escorial. Estudios inéditos en el IV Centenario de la terminacion de las obras. Madrid, CSIC, 1987, págs. $245-248$.

9 Sigüenza, op. cit., pág. 265.

10 "En ésta se echa en ver que en otras andaba muy deprisa y con ganas de acabar", op. cit., Libro IV, discurso XII, págs. 319. La pintura del altar de Santa Ana, primero que hizo Cambiaso en El Escorial, necesitó ser renovada por Tibaldi, en lo tocante al rostro y las manos de la santa.

11 Sigüenza, op. cit., pág. 331. Palomino (op. cit., pág. 798) declara: «no hizo cosa Luqueto, en que menos complaciese a los del arte, por haberse aquello dirigido por dictámenes de teólogos de orden de Su Majestad". También se ocupó de la pintura de los cuarto del rey junto con Lazzaro Tavarone ("hartas cosas en breve tiempo"). Es notorio que por aquellas fechas el Cambiaso ostentó un papel hegemónico entre los pintores activos en El Escorial poco acorde con la idea de que su arte no mereció aprobación. Como refiere L. Magnani (Luca Cambiaso da Genova all'Escorial. Genova, 1995, págs. 253 y ss.), Cambiaso estuvo autorizado a trabajar con colaboradores, y de ello se hubo de inferir la mermada calidad del grueso de sus pinturas escurialenses frente a sus trabajos genoveses.

12 Ibid., pág. 331. Un análisis minucioso de la Gloria en Rosemarie Mulcahy, La decoración de la Real Basilica del monasterio de El Escorial, págs. 81-111. 
Aparte de estos trabajos escurialenses, que se cuentan salvo excepciones entre lo menos notable de lo salido de su mano ${ }^{13}$, son pocas las obras de Luca Cambiaso localizadas en España, desde una desaparecida Susana adquirida por Velázquez en Italia (1634) con otras diecisiete pinturas, que estuvo en el Alcázar de Madrid (1666), pasando por Cristo sostenido por un ángel, que Ceán menciona en el Palacio Real nuevo, hasta la Lucrecia que fue de Carlos II, el Eros durmiente y la Sagrada Familia con San Juan Niño, todas ellas pertenecientes al Museo del Prado 14. Mención especial merece La Verdad, en contemplación de la Justicia, triunfante sobre la muerte, de los Duques de Alba, inspirada en la Leda de Leonardo y antes atribuida a Francesco Vanni y tenida por una Alegoría de la Vanidad ${ }^{15}$. Ni el testamento del artista ni el inventario de sus bienes arrojan por otro lado información sobre pinturas ${ }^{16}$.

$\mathrm{Al}$ actualizado catálogo de la obra de Cambiaso ${ }^{17}$ hay que incorporar a nuestro juicio algunas otras creaciones localizadas en España.

Pintura a todas luces suya y hasta ahora olvidada es una bella composición de Venus y Cupido (lienzo; 91,5 x $117 \mathrm{~cm}$. Fig. 1) subastada en Madrid en $1977^{18}$, de la que nada hemos podido establecer sobre procedencia y paradero. Como sucede por lo común con sus creaciones mitológicas, corresponde al momento aún temprano de su trayectoria, entroncado en la tradición pictórica manierista posperinesca y del Pordenone -bien que en el tono dulcificado y simplificado de su maniera piccola ${ }^{19}-$, a la que incorpora acentos venecianos, y ha de ser en cualquier caso anterior a su viaje a España. Como en la versión del Art Institute de Chicago, aunque carente de su lirismo y de su rotundidad plástica, Venus aparece recostada en su lecho con Cupido, con quien mantiene un cariñoso diálogo teñido de manierista afectación. La disposición compositiva

13 Se incluyen cinco altares, seis escenas de la batalla de Lepanto, las pinturas del cuarto del Rey, las del coro (Gloria y escenas de la Vida de San Jerónimo y de San Lorenzo, algunas pintadas por Cincinato; Anunciación), y del presbiterio (Coronación de la Virgen), un Cristo a la columna, del que al parecer hubo dos versiones (una de ellas, en muy mal estado, referida por Poleró y no localizada ya por Zarco, y otra en la «aulilla» del prior, citada por Palomino, Ceán...) y la pintura de Pilatos presentando Cristo al pueblo, en el claustro grande, sobre la celda del prior. Sobre todo ello Bertina Suida Manning y William Suida, Luca Cambiaso. La vita e le opere. Milán, Casa Editrice Ceschina, 1958, págs. 125 y ss.; con anterioridad Julián Zarco Cuevas, Pintores italianos en San Lorenzo el Real de El Escorial (1575-1613). Madrid, 1932. Para el estado de la cuestion, $c f$. L. Magnani, op. cit.

14 Igualmente en Bertina Suida Manning y William Suida, Luca Cambiaso. La vita e le opere., págs. 132-133.

15 La atribución a Cambiaso es de B. Suida Manning «Una obra Maestra de Luca Cambiaso en la colección del Duque de Alba en Madrid", Archivo Español de Arte, XXV, 1952, págs. 152-159. La identificación del tema se debe a Pita Andrade (Sobre un cuadro atribuido a Luca Cambiaso" A.E.A., XXVI, 1953, pág. 253), quien refiere su adquisición en Florencia en 1817.

16 Cf. Fernando Marias, «Luca Cambiaso: testamento escurialense e inventario de sus bienes», Archivo Español de Arte, LII (1979), págs. 83-86. El testamento de Cambiaso data de 5 de septiembre de 1585, un día antes de su defunción. El 2 de junio de 1586, su hijo Orazio, con poder de sus hemanos Pomponio, Aurelio, Bautista y Ottavio, reclamó a Nicolao Granello, en calidad de depositario, los bienes que quedaron por el fallecimiento de su progenitor. La escasez de pertenencias y la total ausencia de pinturas e instrumentos artísticos resulta sorprendente y mueve a dudar que el inventario sea de la totalidad de sus bienes.

17 Además de la monografía de Suida Manning (op. cit.), Giulia Biavati Frabetti, «Affreschi inediti di Luca Cambiaso", Bolletino dei musei civici genovesi, VI, 16-18 (1984), págs. 25-51, y Giulio Fabretti y Anna Maria Gabrielli: Luca Cambiaso e la sua fortuna. Génova, Galleria dell'Accademia, 1956; Lazzaro M. De Bemardis (coord), La pittura a Genova $e$ in Liguria. Genova, 1987 -ver voz "Luca Cambiaso», por P. Torriti, en vol. I, págs. 195-222-; también, P. Rotondi, "Apunti sulla attività giovanile di Luca Cambiaso", Cuaderni della Soprintendenza alle Gallerie della Liguria, n. 4, Genova, 1956, y «Note sul Cambiaso e sul Bergamasco in San Matteo a Genova», en Arte Lombarda, IX, 1964, 1, págs. 115-124, o en el Omaggio a Luca Cambiaso (Moneglia, 1927-El Escorial, 1985). Restauri e proposti Catálogo de la exposición celebrada en el oratorio de la Santa Cruz de Moneglia. Génova, 1985; y, sobre todo, el reciente estudio global de Lauro Magnani (op. cit.). Sobre Cambiaso dibujante, Wolfgang Kröning, "Zeichungen von Luca Cambiaso in Köln", Arte Lombarda, IX, 1964, 1, págs. 125-130, y especialmente Dante Bernini y Caterina Bon Valsassina, C.: Luca Cambiaso e le sua cerchia. Disegni inediti de un album palermitano del 700, catálogo de la exposición, Génova, 1985.

18 Serarte, S.A. Subasta núm. 3. Madrid, Diciembre, 1977. Lote 120. Como Escuela italiana del siglo xvII.

19 S. J. Freeberg, Pintura en Italia, 1500-1600. Madrid, 1978, pág. 601. 
es muy distinta, aunque los ingredientes narrativos son los mismos. Cupido, con el arco en sus manos y carcaj a la espalda, se apoya jugueteando en las rodillas de Venus, quien le acaricia con expresión algo cansina y levanta la diestra con gesto amonestador. En muchos aspectos la figura de la diosa viene a ser una reinterpretación de la pintada en la versión de Venus y Adonis de la Galleria Borghese, en Roma, aunque con muy distinto logro y factura, y Cupido viene a ocupar el lugar de Adonis y mantiene en lo esencial la misma disposición, sentado sobre el lecho, de espaldas y en algo dislocada torsión, cruzando el brazo izquierdo por delante de las piernas de la diosa. El juego de planos divergentes, derivado del zigzagueante escorzo de Venus y la alambicada torsión de Cupido, se resuelve en un esquema trapezoidal de cuerpos desnudos, entre los doseles rojos y las blancas ropas del lecho. Como tantas veces ocurre en Cambiaso, el efecto es decididamente geométrico, tanto por el encuadre perspectívico de la composición, de desarrollo oblicuo, como por el tratamiento anatómico de las figuras, sin que tal reduccionismo plástico de esta manera cúbica llegue a rebajar la atmósfera de intimidad que envuelve la escena.

En la capilla del Cristo del Perdón del monasterio de San Juan de los Reyes, en Toledo, cuelga un lienzo de la Piedad (1,34 × 1,03 m. Fig. 2 y 3), frecuentemente olvidado o mencionado como obra de Luis de Morales ${ }^{20}$, que es, a nuestro juicio, pintura enteramente suya. Nos encontramos ya ante un Cambiaso de muy distinta sensibilidad y estirpe pictórica.

La composición, resuelta con un horror al vacío que intensifica el dramatismo del episodio, muestra a la Virgen, San Juan y María Magdalena con Cristo, al pie de la cruz, como un compacto grupo de formas sólidas y contenida emoción cuya opresiva proximidad anula cualquier otra dimensión espacial y narrativa. La figura de Cristo se proyecta hacia el espectador en un fuerte escorzo, en disposición sedente a los pies de la Virgen y enmarcada por santo sudario, demandando una atención devocional preferente, como corresponde a su dimensión eucarística. Toda la intensidad del tema, plasmado de forma esencial y sin grandes concesiones, se traduce en los rostros, donde Cambiaso pone a prueba su capacidad para mostrar de forma convincente el retrato sereno y dramático de la muerte, en la figura de Cristo, la del profundo y agónico dolor de una madre, en la Virgen, junto con la conmovida expresión de la Magdalena y el acentuado gesto de angustia y fervor del discípulo amado, atendiendo de modo particular a la expresión de los ojos. En el aspecto cromático el dominio de los tonos fríos y terrosos, sin atender a complacencias pictóricas, parece reforzar el sentido pietista, pero el deterioro de barnices, veladuras y pigmentos contribuye en exceso a la apariencia seca y monocromática del lienzo. Las ropas violáceas de la Magdalena, la túnica púrpura y el oscuro manto azul de la Virgen y la tonalidad ocre de las ropas de San Juan componen un denso fondo cromático, con algún destello de apagada luminosidad en las limitadísimas áreas de celaje, sobre el que resalta la cárdena anatomía de Cristo y la blancura del sudario. Se llega así a una visión directa e intensa del tema evangélico, con la fuerza de lo esencial, apoyada en una apurada y casi descarnada economía cromática, y una similar simplicidad compositiva, y la inmediatez sin paliativos de unas figuras comprimidas en un cerrado primer término que se imponen al devoto espectador.

La pintura podría haber pertenecido al convento de Nuestra Señora del Carmen de Pastrana, de donde proceden varias de la obras que hoy adornan los muros del monasterio toledano ${ }^{21}$. No hay constancia escrita sin embargo de que así fuera, aunque son ciertamente muchas las lagunas existentes sobre las pinturas, retablos e imágenes de aquel templo de los descalzos y de la er-

\footnotetext{
20 Fernando Marías y Natividad Sánchez Esteban, Museos de Toledo. Madrid, Electa, 1995, pág. 39. Como Descendimiento de Luis de Morales. Nada se dice en el Inventario artístico de Toledo capital, I. Madrid, 1983, págs. 178 y ss.; y tampoco hay referencias en las guías y estudios artísticos clásicos sobre Toledo (Ramírez de Arellano, Parro, Ainaud de Lasarte, etc.).

21 Testimonio verbal del prior de la comunidad. Marías y Sánchez Esteban (op. cit., pág. 39) señalan que entre otras pinturas procedentes del convento, ya entonces franciscano, de Pastrana, está el retrato de Duns Scoto.
} 


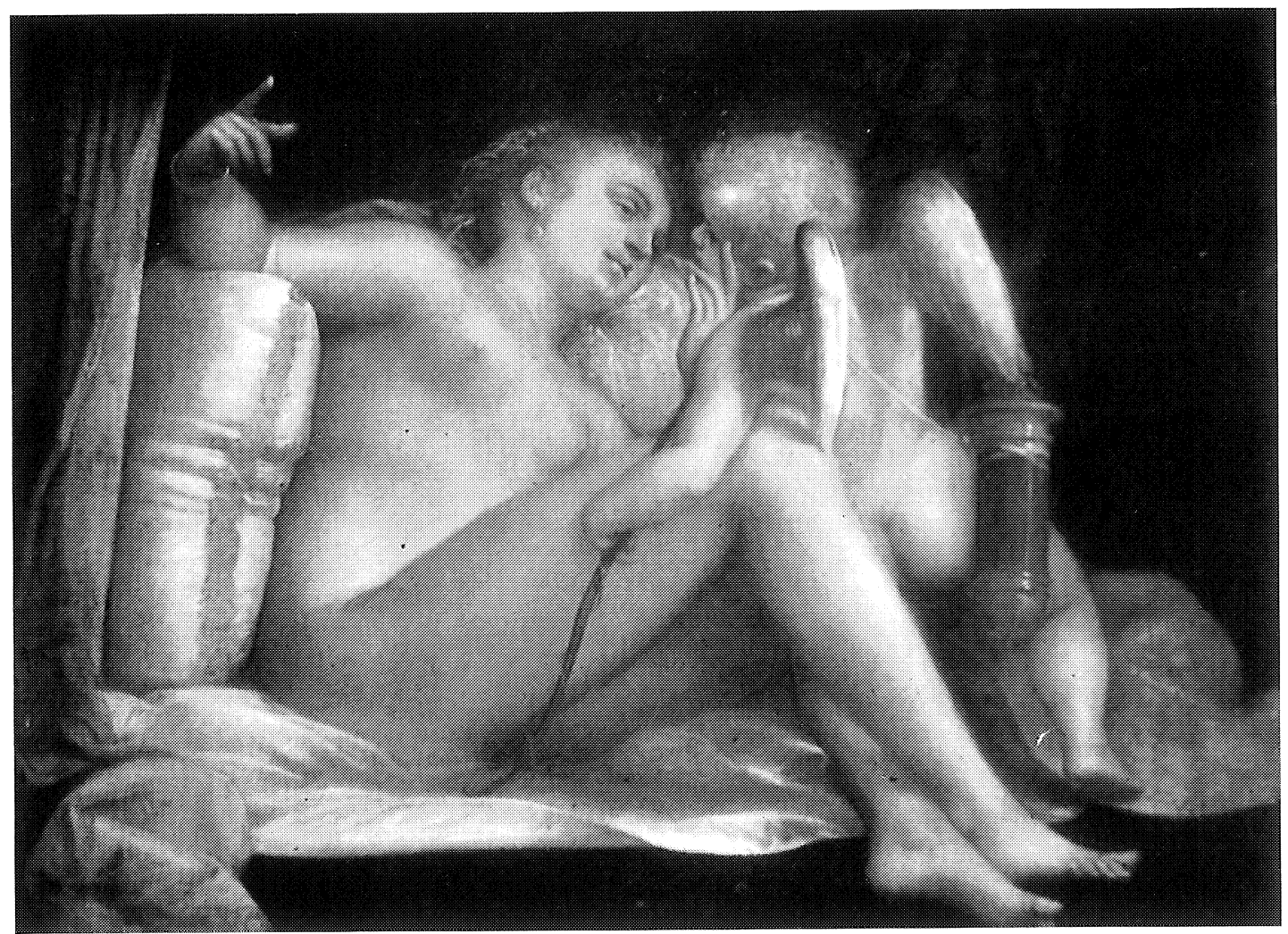

Fig. 1. Luca Cambiaso, Venos y Copido. Paradero desconocido.

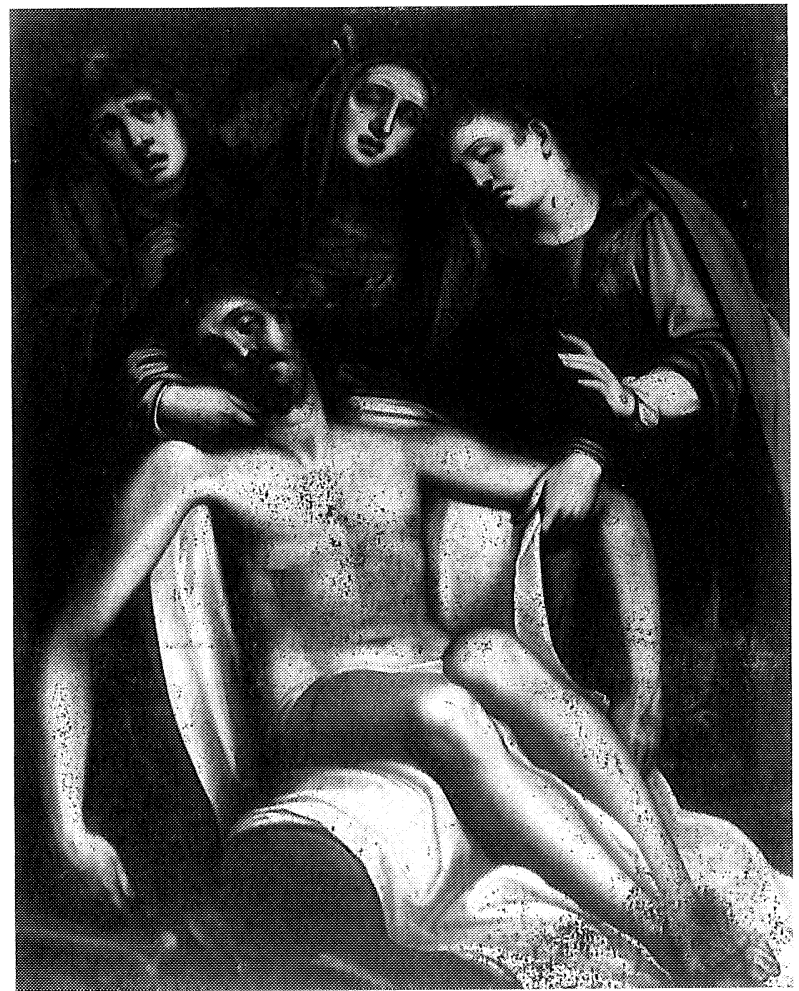

Fig. 2. Luca Cambiaso, Piedad. Toledo, San Juan de los Reyes. 
mita de San Pedro ${ }^{22}$. La razón de la llegada a esta localidad alcarreña de una pintura así pudiera estar en relación con los propios duques de Pastrana, impulsores y patronos de las fundaciones carmelitanas en la villa y protectores de otras comunidades religiosas, para quienes trabajaron algunos artistas genoveses y milaneses en las decoraciones palaciegas ${ }^{23}$. Toda investigación documental ha resultado empero infructuosa, por lo que tal estimación ha de valorarse por el momento como mera conjetura.

En lo estilístico y en lo compositivo estamos ante una obra próxima a la Piedad de la Galería del Pallazzo Rosso (Génova), datable por 1575 o algo posterior a esta fecha, y al Descendimiento de Santa Clara de San Martín de Álbaro, entroncadas de una u otra forma en la más renombrada Piedad de la capilla Sauli en Santa Maria Assunta y San Sebastiano de Carignano, en Génova (1571) 24, con la que guarda aún mayor semejanza en lo figurativo y en la atmósfera espiritual. Esencialmente la versión toledana del tema viene a ser una reinterpretación condensada de esta pintura en la que los cuatro personajes, ahora únicos, mantienen en lo esencial los mismos rasgos anímicos y figurativos El escorzo de Cristo ofrece sin embargo mayor similitud con el de un dibujo del Entierro de Cristo ${ }^{25}$, en el recurrente juego de variaciones y recreaciones figurativas a que nos tiene acostumbrados el genovés. No hay duda de que una pintura así ha de ser datada en fechas inmediatas a su llegada de Italia, si es que fue realmente realizada ya en España.

En el convento de los Carmelitas Descalzos del mismo Toledo hay una muy aceptable copia de la ya mencionada Pietà del Palazzo Rosso bajo uno de los arcos que pudieron servir para las estaciones del claustro, pero en modo alguno ha de ser obra del genovés y aun es dudoso que lo sea de alguno de sus discípulos; antes bien parece obra del siglo XIX o muy retocada por entonces.

Del convento de las bernardas regulares de Nuestra Señora de la Asunción (bernarditas) de Toledo procede por otro lado un muy deteriorado lienzo la Oración en el Huerto $(2,07 \times 1,60 \text { m. Fig. } 4)^{26}$, que cuelga en una de las estancias del convento también cisterciense de San Clemente, al que se incorporaron ya en este siglo las pocas integrantes que aún quedaban de aquella comunidad. La composición, teñida del mismo espíritu religioso que la

22 Nada hemos podido localizar en la escasa documentación existente sobre el convento, ni en las diversas cuentas de los duques (B. N.).

Un agotado don Antonio Ponz desperdició por 1777 la oportunidad de dejar testimonio de cuanto había en la villa y en sus templos (Viage de España, ed. Madrid, 1947, pág. 127: «...determiné llegar a Almonacid, que todavía distaba dos leguas de Pastrana. Pasé adelante por fuera de la villa y junto a uno de los primeros conventos que los carmelitas Descalzos tuvieron en España; y auque yo tenía especie de que en su iglesia había unas pinturas de Juan Narbuk, llamado en esta religión fray Miseria, era tanta la que yo llevaba conmigo que no estaba para fiestas ni curiosidades...»). Mariano Pérez y Cuenca (Historia de Pastrana y sucinta noticia de pueblos de su partido. Madrid, 1871, pág. 72) señala que a raíz de la desamortización las imágenes y pinturas se llevaron a Guadalajara el 22 de diciembre de 1839: El 2 de marzo de 1845 el mismo Pérez y Cuenca logró de autorización de Su Majestad para recuperar algunas de estas pinturas e imágenes, que en parte se llevaron a la Colegiata. En las parciales descripciones de las pertenencias del convento y de la ermita de San Pedro, en parte tomadas de las «Memorias y apuntamientos para la historia de Pastrana» de D. Francisco José Fernández de Beteta, no consta nada que pueda relacionarse con esta pintura de Cambiaso. Otro tanto hay que decir por lo que toca a la Colegiata y al convento franciscano.

23 J. M. Muñoz Jiménez, Arquitectura del Manierismo en Guadalajara, 1987, pág. 371

24 Dibujo en los Uffizi, núm. 7.025. Relacionado con santo Entierro de la Academia Lingüistica de Génova. Pintura también cercanas por estilo, composición y temática son además la Piedad de la Galería Nacional de Arte Antiga, de Roma (también citada como de la Villa Caprarola), y las versiones del Descendimiento de Santa Margarita Ligur (parroquial y S. María Assunta a Nozarego), tenidas por obras de taller.

25 Cf. Luca Cambiaso e le sua cerchia. Disegni inediti de un album palermitano del 700. Catálogo de la Exposición, Génova, 1985 , pág. 41 , núm. 33 , invierno, $87-88$.

26 Con marco original y en muy mal estado de conservación (algunas áreas muy barridas, arañado y con desgarros); ha perdido veladuras y barnices. No hay vestigios visibles de firma o data. 

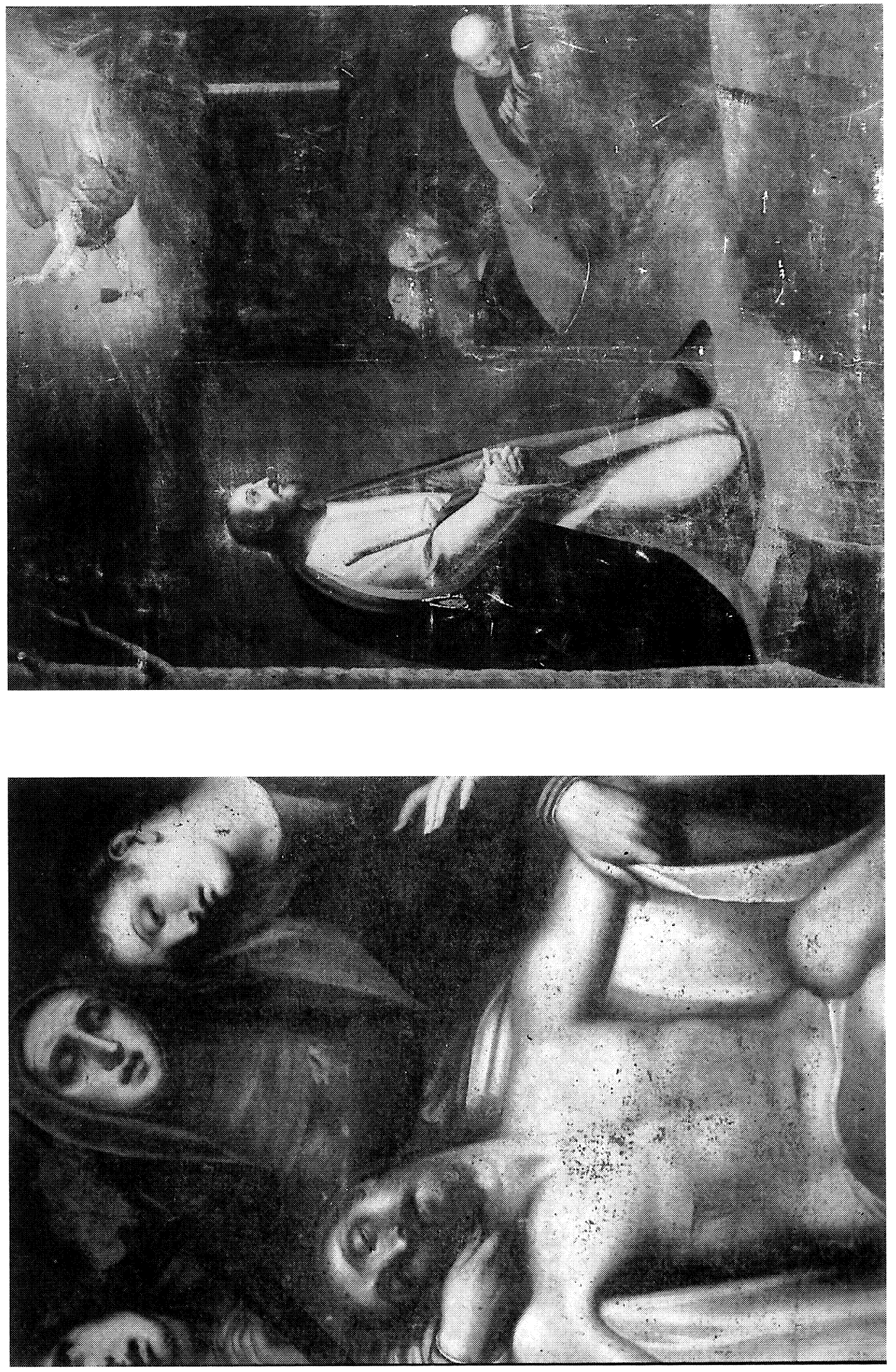
Piedad ${ }^{27}$ y de la mayoría de sus notturni, obedece casi por entero a la de la capilla Cavanna de la iglesia de la SS. Annunziata de Portoria, para la que, según Suida, Cambiaso se inspiró en un panel de Perino del Vaga perteneciente la predela de la Natividad de la iglesia genovesa de Sçanta María de la Consolazione. Pero la figura de Jesús evoca más de cerca la de Cristo bendiciendo a la Virgen y a las Santas Mujeres de la Galería Nacional del palacio Spinola. Cabe anotar por lo demás pequeñas diferencias en la disposición del ángel, de Cristo -aquí con las manos unidas- y de los apóstoles, y la presencia de un árbol vertical que enmarca la composición por el extremo izquierdo. Todo parece indicar no obstante que la ejecución no hubo de ser de Cambiaso, sino obra de taller o, más probablemente, uno de sus discípulos o colaboradores, bastante alejado ya de los logros del maestro. La nocturna oscuridad de Getsemaní se diluye por la luminosa irrupción del ángel portador del cáliz, cuya luz cae directamente sobre la figura de Cristo, resuelta en una esquematización geométrica muy de Cambiaso, aunque un tanto excesiva, con una demasiado elemental planitud en las ropas, rosáceas y azules, y una total carencia de expresividad facial. No mejor logradas están las figuras de los tres apóstoles durmientes, con una reiteración en los rostros de perfil que poco dice en favor del artífice de la pintura. Bastante más convincente resulta el grupo que conducido por Judas irrumpe en tropel en el huerto de los Olivos, emergiendo de la profunda oscuridad reinante entre antorchas y destellos lunares. Pero la general sequedad de las formas y de las luces la planitud cromática tiene que ver también con limpiezas inadecuadas y con posibles repintes ${ }^{28}$.

Aunque nada prueba la datación de la pintura, que bien pudo llegar por donación al convento de la Asunción, en el que al parecer colgaba en uno de los muros laterales de la capilla mayor, la comunidad de bernardas regulares se estableció en Toledo sólo después de 1604, una vez se otorgaron las licencias papal y real pertinentes para que se desplazaran aquí algunas de las religiosas del convento de Santa Ana de Valladolid, dando cumplimiento a la disposición testamentaria fundacional otorgada por Hernán Pérez de la Fuente en 8 de febrero de $1598{ }^{29}$. Lamentablemente el primer libro de cuentas sufrió temprano extravío, recomenzándose de nuevo en $1616^{30}$, y no hay datos de en qué momento la pintura se incorporó al monasterio.

\section{Fernando Collar de CÁceres} Universidad Autónoma

\footnotetext{
27 Sobre el comprometido sentido religioso de las pinturas de Cambiaso, Lauro Magnani, «Luca Cambiaso tra due "riforme"", en Arte Lombarda, 1978, págs. 87-94; partiendo en particular de las reflexiones de L. Profumo Muller, "Le opere "geometrizzate" di Luca Cambiaso", Arte Lombarda, XV, 1970/72, 38, y E. Battisti, "Riforma e Contrariforma», en Enciclopedia Universale dell'Arte, vol. XI, Florencia, 1963, col. 386. En general se asocia a sus contactos con los jesuítas y con la atmósfera religiosa impulsada por el obispo Cipriano Pallavicino y con la corriente que representa Catalina de Génova.

28 Sólo una esmerada restauración podría ayudar a determinar la verdadera calidad de esta maltrecha y casi irrecuperable pintura. Véase nota 26.

29 La licencia de Clemente VII fue trasmitida por el nuncio apostólico el 20 de agosto de 1604, y el monarca otorgó la suya al monasterio de Santa Ana a 11 de enero de 1605. Sobre estos y otros aspectos referidos a la fundación cf. Carmen Torroja Menéndez, Catálogo del archivo del monasterio de San Clemente en Toledo. Toledo, IPIET, 1973.

30 A.H.N. CLERO, Libro. 15.016. "Libro donde se Rreciuen las quentas del Convento de Nuestra Señora de la

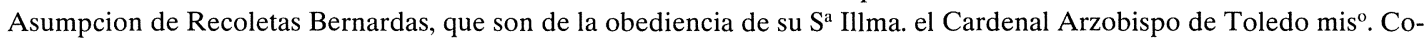
mençose a escriuir año de 1616", fol. 0: "En la ciudad de Toledo a diez y seis dias del mes de abril de mill y seiscientos y diez y seis años, su sa el sor. obpo. de Troia del Consejo del Rey Nro. Sor., Visitador General de esta Ciud. y todo su arcobpado. y superintendente y administrador gral. de todos los conuentos y casa de religion que son de la obediencia de su ra., Dixois ${ }^{a}$ Illma. El Cardenal Archipo. de Toledo, miso. e ttra. Dixo que por quanto su $S^{a}$ tomo unas largas quentas a doña Guiomar de St. Joseph abbadesa del conuento de la assumpcion de recoletas Bernardas de esta ciud. y a Quiteria de St. Joseph Prouisora del dho conuento.......y poque agora a noriçia de su $\mathrm{s}^{\mathrm{a}}$ es venido que el dho libro de quenta se a perdido y no pareçe (sic) aunque se a hecho mucha diligencia para buscarle, y porque conviene tomar las quentas del dho Monestro. de todo el año entero de mill y seis ${ }^{\circ}$ y quinze $=$ Por tanto y para que la acienda ande con claridad entendida $y$ ajustadas las quentas del dho Monesterio, mando su $s^{a}$ que luego sin dilaçon se tomen quentas la Abadesa y Prouisora del dho monasterio......, declarando como su $\mathrm{s}^{\mathrm{a}}$ declara desde agora para entonces que si pareciese el dho libro que anssi se perdio se quedan en su fuerza y vigor las quentas que en el fueron tomadas...... ante mi Pedro Jurado Palomino».
} 